\begin{tabular}{|c|c|}
\hline 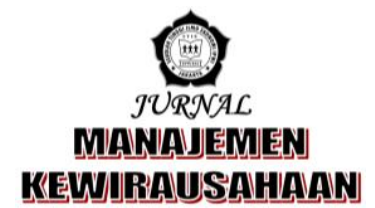 & $\begin{array}{r}\text { p-ISSN 1858-1048 } \\
\text { e-ISSN 2654-9247 } \\
\text { http://ejurnal.stieipwija.ac.id/index.php/imk } \\
\text { DOI: http://dx.doi.org/10.33370/imk.v16i1.312 } \\
\text { Jurnal Manajemen Kewirausahaan Vol. 16 No. 01 - Juni } 2019 \\
\text { Submit: 13 Mei 2019; Review: 17 Jun 2019; Publish: 30 Jun } 2019\end{array}$ \\
\hline
\end{tabular}

\title{
PENGARUH PENGENDALIAN STRES KERJA DAN PENGEMBANGAN KARIER TERHADAP KINERJA PEGAWAI
}

\author{
Oleh: \\ Meryati \\ merry.santoso@catlover.com \\ Sekolah Tinggi Ilmu Ekonomi IPWI Jakarta
}

\begin{abstract}
ABSTRAK
Pengelolaan stres kerja dan pengembangan karier pegawai merupakan dua faktor yang diduga relatif besar dalam mempengaruhi kinerja pegawai PT. Woori Bio Corpora, Jakarta Selatan. Untuk mengetahui pengaruh keduanya dilakukan penelitian ini dengan tujuan mengetahui pengaruh pengelolaan stres kerja dan pengembangan karier pegawai terhadap kinerja pegawai PT. Woori Bio Corpora.

Penelitian ini melibatkan 75 responden yang dipilih sebagai sampel dari populasi sejumlah 150 orang pegawai pada kantor PT. Woori Bio Copora, dan kemudian digunakan teknik penarikan sampel dengan menggunakan model rumus Slovin sehingga diperoleh 75 responden penelitian. Teknik pengumpulan data menggunakan observasi,wawancara dan angket/kuesioner. Kategori jawaban responden penelitian terhadap angket terdiri atas empat skala berdasarkan skala Likert. Dalam pengelolaan data dibantu dengan menggunakan program SPSS, Pengujian statistik yang digunakan adalah dengan perhitungan uji validitas, uji reliabilitas, koefiesien korelasi, koefisien determinasi, uji hipotesa, dan analisa regresi.

Pengelolaan stres kerja dan pengembangan karier terhadap kinerja pegawai PT. Woori Bio Corpora berpengaruh positif terhadap kinerja pegawai dengan persamaan regresi berganda sebagai berikut: $Y=23,921+1,459 X 1+0,323 X 2$.
\end{abstract}

Kata Kunci: pengelolaan stres kerja, pengembangan karier, kinerja pegawai

\section{PENDAHULUAN}

Perusahaan pada dasarnya merupakan organisasi dari sumber daya manusia, sumber daya alam dan sumber-sumber ekonomi lainnya untuk mencapai tujuan. Untuk mencapai tujuan tersebut diperlukan sistem pengendalian manajemen yang memberi jaminan melalui para manajer bahwa organisasi telah melakukan organisasinya secara efektif dan efisien (Davis, 2002:5).

Salah satu faktor yang mempengaruhi tingkat keberhasilan suatu organisasi adalah kinerja karyawannya. Menurut Handoko (2001:135), kinerja karyawan merupakan suatu tindakan yang dilakukan karyawan dalam melaksanakan pekerjaan yang diberikan perusahaan. Setiap perusahaan selalu mengharapkan karyawannya mempunyai prestasi, karena dengan memiliki karyawan yang berprestasi akan memberi sumbangan yang optimal bagi perusahaan. Kinerja karyawan yang baik dengan etos kerja yang tinggi akan membantu perusahaan untuk dapat memenuhi target 
perusahaan, sedangkan bila kinerja karyawan menurun dan buruk maka akan merugikan perusahaan tersebut.

Kesemua hal di atas hanya dapat dicapai karena instansi memiliki pegawai yang berkinerja tinggi dan didukung oleh pegawai yang memiliki kepuasan kerja yang tinggi, karena pada umumnya pegawai yang memiliki kepuasan kerja yang tinggi akan memiliki kinerja yang tinggi pula. Salah satu faktor yang diduga akan meningkatkan kepuasan kerja pegawai adalah pengembangan karier. Pengembangan karier yang sangat penting dalam kehidupan setiap dan semua pegawai, yang mendambakan kemajuan dan perkembangan dalam bekerja. Tidak seorangpun pegawai yang tidak menginginkan kariernya berkembang dan meningkat sesuai dengan harapannya.

Selain faktor pengembangan karier yang berpengaruh terhadap aktifitas pekerjaan bagi karyawan, salah satu faktor lain yang mempengaruhi kinerja karyawan adalah stres kerja. Dimana stres merupakan reaksi emosi dan fisik akibat kegagalan individu beradaptasi pada lingkungan. Dalam hal ini stres terhadap kinerja dapat berperan positif dan juga berperan merusak kinerja karyawan di suatu perusahaan. Handoko (2008:200) menyatakan bahwa stres merupakan suatu kondisi ketegangan yang mempengaruhi emosi, proses berpikir dan konsisi seseorang. Hasilnya, stres yang telalu besar dapat mengancam kemampuan seseorang untuk menghadapi lingkungan yang akhirnya mengganggu pelaksanaan tugastugasnya, berarti mengganggu prestasi kerjanya.

\section{TUJUAN PENELITIAN}

Tujuan penelitian ini adalah sebagai berikut:

1. Untuk menganalisis pengaruh pengembangan karier terhadap kinerja karyawan pada PT. Woori Bio Corpora.

2. Untuk menganalisis pengaruh pengelolaan stres kerja terhadap kinerja karyawan pada PT. Woori Bio Corpora.

\section{TELAAH LITERATUR DAN PENGEMBANGAN HIPOTESIS Stres Kerja}

Stres merupakan suatu tanggapan adaptif, dibatasi oleh perbedaan individual dan proses psikologis, yaitu suatu konskuensi dari setiap kegiatan (lingkungan), situasi atau kejadian eksternal yang membebani tuntutan psikologis atau fisik yang berlebihan terhadap seseorang. Menurut Anwar Prabu (2003:93), stres kerja adalah suatu perasaan yang menekan atau rasa tertekan yang dialami karyawan dalam menghadapi pekerjaannya. Menurut Lazarus (dalam Yuli T, 2003:56) stres hanya berhubungan dengan kejadiankejadian di sekitar lingkungan kerja yang mempunyai bahaya atau ancaman, yang dimaksud dari bahaya atau ancaman itu sendiri adalah ketakutan yang dirasakan seorang karyawan ketika melakukan kesalahan yang dapat mengancam karirnya dalam bekerja.

Menurut Gibson dkk (2008:339) menyatakan bahwa stres kerja adalah suatu tanggapan penyesuaian diperantarai oleh perbedaan-perbedaan individu dan atau proses psikologi yang merupakan suatu konsekuensi dari setiap tindakan dari luar (lingkungan), situasi, peristiwa yang menetapkan permintaan psikologis dan atau fisik berlebihan kepada seseorang.

Menurut Handoko (2001:68) indikator stres kerja dapat dilihat dari gejala berupa berupa tanda-tanda: a) Fisik, yaitu sulit tidur atau tidur tidak teratur, sakit kepala, sulit buang air besar, adanya gangguan pencernaan, radang usus, kulit gatal-gatal, punggung terasa sakit, urat-urat pada bahu dan leher terasa tegang, keringat berlebihan, berubah selera makan, tekanan darah tinggi, atau serangan jantung dan kehilangan energi; b) Emosional, yaitu marah-marah, mudah tersinggung dan terlalu sensitif, gelisah dan cemas, suasana hatinya berubah-ubah, sedih, mudah menangis dan depresi, gugup, agresif terhadap orang lain dan mudah bermusuhan, serta mudah menyerang dan kelesuhan mental; c) Intelektual, yaitu mudah lupa, kacau pikirannya, daya ingat menurun, sulit untuk 
berkonsentrasi, suka melamun berlebihan, pikiran hanya dipenuhi satu pikiran saja; d) Interpersonal, yaitu acuh dan mendiamkan orang lain, kepercayaan pada orang lain menurun, mudah mengingkari janji pada orang lain, senang mencari kesalahan orang lain atau menyerang dengan kata-kata, menutup diri secara berlebihan, dan mudah menyalahkan orang lain.

Dampak stres kerja pada umumnya lebih banyak merugikan karyawan maupun instansi. Pada diri karyawan, konsekuensi tersebut dapat berupa menurunnya gairah kerja, kecemasan yang tinggi, frustasi, dan sebagainya. Konsekuensi pada kayawan ini tidak hanya berhubungan dengan aktivitas kerja saja, tetapi dapat meluas ke aktivitas lain di luar pekerjaan. Tetapi di sisi lain stres juga bersifat positif bagi individu dimana karyawan yang mampu mengatasi dan mengubah stres menjadi motivasi (dorongan) agar lebih maju dimana prestasi kerjanya meningkat, lebih cekatan dalam bekerja, lebih teliti dan mampu menyelesaikan pekerjaan dengan memuaskan. Bagi organisasi konsekuensi negatif yang timbul dari stres kerja bersifat tidak langsung adalah meningkatnya tingkat absensi, menurunnya tingkat produktivitas, dan secara psikologis dapat menurunkan komitmen organisasi, hingga turn over.

\section{Pengembangan Karier}

Menurut Simamora dalam Widodo (2014:107) karir adalah urutan aktivitasaktivitas yang berkaitan dengan pekerjaan dan perilaku-perilaku, nilanilai dan aspirasi seseorang selama hidup orang tersebut. Pengembangan karier adalah kegiatan pengembangan personil agar dapat memenuhi rencana karir memberikan dukungan yang penting terhadap kelancaran jalannya organisasi (Widodo, 2014:107). Sedangkan Rivai (dalam Widodo) pengembangan karier adalah suatu kondisi yang menunjukkan adanya peningkatan jenjang atau status seseorang dalam pekerjaannya sehingga dapat memenuhi kebutuhan. Hal ini didorong melalui penilaian kepribdian khususnya pengalaman dan latar belakang pendidikan.

Dari pendapat ahli dapat ditarik kesimpulan bahwa pengembangan karier adalah suatu proses rangkaian kegiatan untuk meningkatkan kemampuan kerja individu karyawan untuk merencanakan karier dimasa sekarang dan masa depan. Peningkatan potensi manusia dimulai dengan perbaikan gizi dan pengembangan. Dalam bukunya Nutrition and The Brain, Edward Edelson mengetengahkan bahwa gizi meningkat fungsi neurotransmitters yang erat kaitannya kualitas otak. Gizi tidak dapat diabaikan dalam rangka peningkatan potensi manusia.

Setiap kegiatan pembangunan memerlukan tenaga kerja yang bukan saja sanggup dan mau bekerja keras, tetapi juga dapat bekerja dengan bijaksana. Kerja keras saja tidak mempunyai korelasi dengan sesuatu kemajuan. Akan tetapi, bekerja dengan bijaksana dan sistematis sangat erat kaitannya dengan tingkat kehidupan yang tinggi dan kemakmuran. Dengan perkataan lain, tinggi rendahnya kebijakan seseorang dengan bekerja sangat menentukan besar-kecilnya pendapatannya atau penghasilannya. Oleh sebab itu, rencana-rencana pembangunan ekonomi/usaha menggunakan tenaga kerja yang berkualitas tinggi. Tenaga kerja seperti ini dapat dibina jika ada sistem tenaga kerja yang tepat guna (Silalahi, 2010:48).

\section{Program Pengembangan Karier}

Program pengembangan karier dengan tujuan seperti tersebut di atas sangat penting bagi organisasi non profit, karena dapat meningkatkan kepuasan kerja yang berpengaruh pada peningkatan efisiensi, efektivitas, produktivitas, dan kualitas pelaksanaan pekerjaan dan hasilnya. Di samping itu dapat pula memperbaiki sikap pegawai terhadap pekerjaannya, atasannya, rekan sesama pegawai dan pada nilainilai di lingkungan organisasi kerjanya.

Menurut Handoko (2000:123) dalam bukunya "Manajemen Sumber Daya Manusia" menyatakan pengembangan karier (career development) adalah 
peningkatan-peningkatan pribadi yang dilakukan seseorang untuk mencapai suatu rencana karier.

$$
\text { Dengan }
$$

adanya

program

pengembangan pegawai merupakan kebutuhan yang mendasar, baik ditinjau dari segi organisasi maupun pegawainya yang bersangkutan. Bagi pegawai yang dinamis, kebutuhan pengembangan diri merupakan suatu dorongan untuk bekerja lebih giat dan lebih produktif, sehingga membawa pengaruh dalam prestasi kerja selanjutnya. Oleh karena itu, bagi pegawai yang mengharapkan karier, akan lebih baik daripada pegawai yang tidak mengharapkan karier, maka daripada itu pengembangan diri merupakan suatu jalan untuk mencapai cita-cita yang diinginkan dari dirinya sendiri maupun untuk organisasinya.

\section{Kegiatan Pengembangan Karier}

$$
\begin{array}{ccr}
\text { Pengembangan } & \text { karir meliputi } \\
\text { kegiatan-kegiatan } & \text { personal } & \text { yang }
\end{array}
$$
dilakukan untuk mencapai sebuah rencana karir. Kegiatan-kegiatan ini mungkin disponsori oleh departemen SDM atau manajer atau dilakukan tanpa ketergantungan pada departemen SDM. Dengan kata lain, dilakukan secara individual mulai dari perencanaan sampai implementasinya.

\section{Pengembangan Karir Individual}

Tiap orang harus menerima tanggung jawabnya untuk pengembangan karir atau kemajuan karir yang dalam kenyataannya bisa gagal. Sekali komitmen individu ini dibuat, beberapa kegiatan pengembangan karir hendaknya terbukti bermanfaat. Kegiatan-kegiatan itu mengandung beragam segi, yaitu sebagai berikut (Keith Davis dan Werther W. B, 1996):
a) Produktivitas kerja pegawai pekerjaan.
b) Kegiatan yang diketahui umum.
c) Jaringan kerja.
d) Pengunduran diri.
e) Kesetiaan pada organisasi.
f) Mentor dan sponsor.
g) Bawahan sebagai kunci sukses.
h) Kesempatan berkembang.
i) Pengalaman internasional.

\section{Kinerja Pegawai}

Secara morfologis kata kinerja berasal dari kata kerja "Perbuatan melakukan sesuatu; sesuatu yang dilakukan atau diperbuat" (Kamus Besar Bahasa Indonesia, 2001). Sedangkan istilah kinerja itu sendiri adalah "Sesuatu yang dicapai; prestasi diperlihatkan; kemampuan kerja" (Kamus Besar Bahasa Indonesia, 2001). Berdasarkan arti tersebut bahwa kinerja merupakan hasil pekerjaan yang diperlihatkan seseorang dalam melaksanakan hasil pekerjaannya tugasnya dan sudah tentu bahwa hasil kerja seseorang tersebut merupakan prestasi yang dia raih dalam mencapai tujuan organisasi.

Menurut Prof. Dr. Bennett Silalahi, Ph.D. (2014:85), kinerja adalah luaran kerja yang dapat diukur. Dengan demikian, maka ada perbedaan antara kinerja dengan performance appraisal yang berarti bagaimana seseorang melaksanakan tugas dan tanggung jawabnya sesuai dengan prosedur dan organisasi kerja yang telah diterapkan oleh pihak manajemen.

Kinerja merupakan suatu hasil pekerjaan atau luaran yang dapat diukur. Berdasarkan analisa suatu pengukuran pekerjaan tersebut kita akan mendapatkan data apakah hasil kerja seseorang itu baik atau tidak.

\section{Ukuran Kinerja Pegawai}

Dalam pelaksanaannya penilaian kinerja pegawai antara organisasi satu dengan organisasi lainnya menggunakan ukuran yang tidak sama tergantung pada kriteria dan persyaratan yang ditentukan organisasi yang bersangkutan.

Sementara itu, Flippo (2008:62) mengemukakan bahwa faktor-faktor untuk mengukur kinerja seorang pegawai, yaitu:

1) Kuantitas dan kualitas kerja, meliputi keluaran, tidak hanya mempertimbangkan tugas-tugas reguler tetapi meliputi ketetapan, keterampilan, ketelitian, dan kerapian.

2) Ketangguhan, yaitu mengikuti perintah, kebiasaan, keselamatan, inisiatif, ketapatan waktu dan kehadiran. 
3) Sikap terhadap perubahan pekerjaan, teman sekerja, dan kerjasama.

Berdasarkan dari pandangan dan pemikiran di atas, dapat diketahui kriteria dan ukuran yang dapat digunakan untuk menilai kinerja pegawai. Semua faktor tersebut pada dasarnya saling melengkapi dan dapat menjadi acuan untuk mengukur kinerja pegawai dalam rangka usaha pembinaan dan pengembangan.

Kinerja adalah sesuatu yang dicapai atau prestasi yang diperlihatkan oleh seorang pegawai dalam melaksanakan tugas pekerjaannya. Unsur-unsur kinerja meliputi:

1) Kesetiaan

a) Kesetiaan adalah kepatuhan seseorang kepada pimpinannya dalam melaksanakan tugas;

b) Menaati segala aturan yang diterapkan pimpinan;

c) Melaksanakan perintah dan tugas yang dibebankan.

2) Kedisiplinan

a) Disiplin dalam jam kerja;

b) Disiplin dalam penyelesaikan tugas;

3) Prestasi Kerja

a) Pelaksanaan tugas dengan bergairah;

b) Menerima tugas tambahan dari pimpinan;

c) Peningkatan kemampuan dan pengetahuan, serta pengembangan karier

4) Tanggung Jawab

a) Bertanggung jawab atas tugas yang harus dilaksanakan;

b) Berani mandiri dalam melaksanakan tugas dan berani mengambil resiko;

c) Tidak menolak tugas dan berusaha untuk menyelesaikan tugas tersebut.

5) Kerjasama

a) Koordinasi dengan rekan kerja dan pimpinan dalam menyelesaikan tugas;

b) Berkonsultasi dengan pimpinan bila menemukan hambatan dalam melaksanakan tugas.
6) Prakarsa

a) Kreatif dan mencari ide-ide baru yang lebih baik;

b) Berperan aktif memberikan saran, ide dan gagasan;

7) Kepemimpinan

Berperan aktif dalam organisasi yang berhubungan dengan jabatan.

\section{Penilaian Unjuk Kerja}

Penilaian unjuk kerja merupakan suatu keharusan untuk mengukur tingkatan perilaku kerja seseorang pegawai. Perilaku kerja dipengaruhi beberapa unsur (Manullang, 2004:18):

a) Imbalan finansial yang memadai;

b) Kondisi fisik yang baik;

c) Keamanan;

d) Hubungan antarpribadi;

e) Pengakuan atas status dan kehormatan;

f) Kepuasan kerja.

1) Imbalan Finansial yang Memadai. Artinya upah yang diterima oleh seorang pegawai itu apakah sudah sesuai dengan tugas dan pekerjaannya untuk memenuhi kebutuhan hidup pegawai itu. Dalam hal ini juga menyangkut kesejahteraan bagi pegawai itu.

2) Kondisi Fisik yang Baik. Seorang pegawai yang kondisi fisiknya sedang baik akan mempengaruhi perilaku kejanya. Seorang yang sedang dalam keadaan sakit misalnya, maka perilaku kerjanya akan terganggu atau bahkan tidak dapat melakukan tugasnya.

3) Keamanan. Perasaan aman, nyaman dan tenteram akan mempengaruhi perilaku kerja seorang pegawai merasa dirinya aman dalam melaksanakan tugasnya.

4) Hubungan antar Pribadi. Hubungan sosialisasi antara pegawai satu dengan yang lain menimbulkan sikap kerja sama yang baik antara sesama pegawai, membutuhkan team work sehingga tugas kerja dapat dilaksanakan dan baik untuk mencapai tujuan organisasi.

Pengakuan atas Status dan Kehormatan. Perlu adanya pengalaman yang baik atas status yang dijabat bawahan 
sehingga merasa penghormatan atas jabatan/tugas yang diberikan kepadanya.

5) Kepuasan Kerja. Suatu kondisi seseorang merasa puas atas tugas yang diberikan kepadanyta serta pegawai itu merasa ditempatkan pada jabatan yang sesuai dengan kemampuan yang dimilikinya. Hal ini akan berpengaruh terhadap penilaian kerja seseorang. Pengaruh psikologis ini dipengaruhi keluaran (output) kerja.

Manajemen kinerja adalah suatu investasi di muka, sehingga Anda dapat membiarkan pegawai Anda melaksanakan pekerjaan mereka. Mereka akan tahu apa yang diharapkan untuk mereka lakukan, keputusan apa saja yang dapat mereka ambil sendiri, sebaik apa mereka harus melakukan pekerjaan, dan kapan Anda perlu dilibatkan. Lakukan dengan tepat, maka manajemen kinerja dapat menghemat waktu dan usaha Anda. Tidak ada satu cara standar yang dapat diterapkan untuk setiap manajer dengan setiap pegawai dalam segala situasi.

Menurut Silalahi (2014:2) luaran kerja dipengaruhi oleh perilaku dan perilaku dipengaruhi oleh beberapa unsur:

a) Imbalan finansial yang memadai.

b) Kondisi fisik yang baik.

c) Keamanan.

d) Hubungan antar pribadi.

e) Pengakuan atas status dan kehormatannya.

f) Kepuasan.

\section{Kerangka Penelitian}

Sesuai dengan uraian tersebut di atas, peneliti mengemukakan kerangka penelitian sebagai berikut:

Gambar 1

Kerangka/Konstelasi

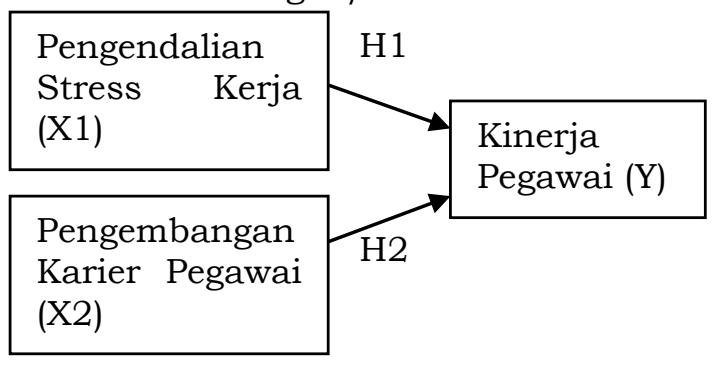

Berdasarkan gambar kerangka penelitian tersebut, maka dapat diajukan hipotesis sebagai berikut:

1. Terdapat pengaruh pengembangan karier terhadap kinerja karyawan pada PT. Woori Bio Corpora.

2. Terdapat pengaruh pengelolaan stres kerja terhadap kinerja karyawan pada PT. Woori Bio Corpora.

\section{METODE PENELITIAN}

Jenis dan rancang penelitian dapat dikelompokkan sesuai tujuan penelitian, pendekatan, tingkat eksplanasi dan jenis data. Penelitian ini tergolong penelitian asosiatif yaitu penelitian yang bersifat mencari hubungan atau pengaruh antara satu variabel dengan variabel lainnya.

\section{Sampel Penelitian}

Penentuan sumber data bergantung pada masalah yang akan diteliti, serta hipotesis yang akan diuji kebenarannya. Pada penelitian ini yang menjadi populasi penelitian adalah para pegawai Kantor PT. Woori Bio Corpora Jakarta Selatan, yaitu sebanyak 100 orang pegawai. Jumlah sampel (responden) dalam penelitian ini adalah sebanyak 75 orang pegawai pada Kantor PT. Woori Bio Corpora Jakarta Selatan.

Penelitian ini penulis mengumpulkan data yang berhubungan dengan masalah yang sedang diteliti, adapun teknik yang digunakan yaitu sebagai berikut:

1. Penelitian kepustakaan penelitian yang dilakukan dengan cara membaca dan mempelajari:

a) Literatur yang terdapat di perpustakaan, dengan maksud untuk menempatkan landasan teoritis.

b) Mengenai masalah pokok yang sedang dibahas.

2. Penelitian Lapangan

a) Penelitian terhadap objek yang diteliti dan pencarian data pada objek penelitian dengan cara observasi, wawancara, penyebaran angket dan kuisioner. 


\section{Operasionalisasi Variabel}

Dalam penelitian ini variabel bebas adalah pengendalian stress kerja (X1) dan pengembangan karier pegawai (X2). Variabel terikat adalah kinerja pegawai (Y).

1) Faktor pengendalian stess kerja yang menjadi indikator adalah:

a) Strategi Penanganan Individual.

b) Strategi Penanganan Organisasional.

c) Strategi Dukungan Sosial.

2) Faktor pengembangan karier pegawai yang menjadi ukuran meliputi:
a) Efektivitas
Pelaksanaan
Pengembangan Karier Individu.
b) Efektivitas Pelaksanaan
Pengembangan Karier oleh Badan Kepegawaian.

3) Faktor Kinerja Pegawai yang menjadi indikator adalah :
a) Pemahaman akan Program Kerja.
b) Sikap dan Tingkah Laku Kerja.
c) Ketangguhan.
d) Disiplin Kerja.
e) Kualitas dan Kuantitas Kerja.

\section{Metode Analisis \\ Uji Validitas dan Realibilitas}

Kualitas data penelitian sangat tergantung pada kualitas data yang dipakai didalam penelitian. Kualitas data penelitian ditentukan oleh instrumen yang digunakan untuk mengumpulkan data untuk menghasilkan data yang berkualitas. Instrumen penelitian yang baik harus memenuhi persyaratan yaitu valid dan reliabel. Untuk mengetahui validitas dan reliabilitas kuisioner perlu dilakukan pengujian atas kuisioner dengan menggunakan uji validitas dan uji reliabilitas.

\section{Uji Asumsi Klasik}

Uji asumsi klasik yang akan digunakan adalah uji linearitas, uji normalitas, uji multikolonearitas, uji heteroskedastisitas dan uji autokorelasi.

\section{Analisa Regresi Berganda}

Persamaan analisa regresi berganda (dua prediktor) yang digunakan adalah sebagai berikut : $\mathrm{Y}=\mathrm{a}+\mathrm{b} 1 \mathrm{X} 1+\mathrm{b} 2 \mathrm{X} 2$.

$\mathrm{Y}=$ Variabel terikat

$\mathrm{a}=$ Nilai konstanta $\mathrm{Y}$ jika nilai $\mathrm{X}=0$ $\mathrm{b}=$ Nilai arah sebagai penentu ramalan variabel $\mathrm{Y}$

$\mathrm{x}=$ Variabel bebas yang mempunyai nilai tertentu untuk diprediksikan

\section{Uji Hipotesis}

Uji hipotesis merupakan suatu prosedur untuk pembuktian kebenaran sifat populasi berdasarkan data sampel. Manfaat uji hipotesis adalah untuk menguji kebenaran suatu hipotesis, dan menentukan keputusan mana yang akan diterima.

Jika probabilitas $\mathrm{F}$ hitung lebih kecil daripada taraf uji penelitian (sig $\mathrm{F}<\mathrm{a}$ atau $0,000<0,05)$, maka Ho ditolak dan Ha diterima yang berarti pengendalian stress kerja dan pengembangan karier pegawai secara bersama-sama dengan kinerja pegawai.

\section{HASIL DAN PEMBAHASAN Hasil Penelitian}

Suatu data dapat dikatakan valid apabila nilai korelasi (r) hitung data tersebut melebihi nilai korelasi (r) tabelnya. Nilai $r$ hitung adalah nilai-nilai yang berada dalam kolom "Corrected Item Total Correlation" dan nilai korelasi tabel yang diperoleh dari hasil perhitungan $(\mathrm{Df}=\mathrm{N}-2$ dan $=5 \%$ ) Dimana N= 85 adalah sebesar 0,, 2272. Jika $r$ hasil positif, dan $r$ hitung $>r$ tabel, maka butir pertanyaan atau variabel tersebut valid.

\section{Uji Validitas}

Berdasarkan hasil uji validitas 60 item pertanyaan tersebut di atas, ternyata semua instrumen penelitian menunjukkan angka lebih besar dari $r$ tabel. Hal ini menunjukkan bahwa alat ukur yang digunakan telah valid dan dapat digunakan sebagai indikator dalam penelitian ini.

\section{Uji Reliabilitas}

Hasil uji reliabilitas yang disajikan pada tabel di atas menunjukkan bahwa alat ukur yang digunakan $100 \%$ reliabel $(\mathrm{a}>0,6)$ yaitu variabel X1 (pengendalian stress kerja) sebesar 0,970, variabel X2 (pengembangan karier pegawai) sebesar 0,957, dan variabel Y (kinerja pegawai) 
sebesar 0,780. Hal ini menunjukkan bahwa semua variabel bebas dan variabel terikat dapat dinyatakan reliabel.

\section{Uji Asumsi Klasik}

Hasil uji linieritas ditemukan hubungan masing-masing variabel bebas terhadap variabel terikat adalah linier, Hasil uji normalitas dengan menggunakan tes Kolomogorov-Smirnov (KS) tidak ditemukan variabel pengganggu atau residual dalam model regresi, hasil pengujian multikolonearitas tidak ditemukan adanya korelasi di antara variabel bebas, hasil uji heteroskedastisitas dalam penelitian ini dengan cara uji Gjejser menunjukkan nilai sig. semua variabel adalah $>0,05$, artinya tidak ada indikasi heteroskedastisitas, dan uji autokorelasi mendapat hasil bahwa tidak terdapat korelasi antara kesalahan pengganggu pada periode $t$ dengan kesalahan pada periode t-1 (sebelumnya).

\section{Koefisien Korelasi Berganda}

Hasil analisis, salah satunya terlihat dari output sebagai berikut:

Tabel 1

Model Summary ${ }^{b}$

\begin{tabular}{|l|l|r|r|r|c|}
\hline Model & \multicolumn{1}{|c|}{$\mathrm{R}$} & $\mathrm{R}$ Square & $\begin{array}{c}\text { Adjusted } \mathrm{R} \\
\text { Square }\end{array}$ & $\begin{array}{r}\text { Std. Error of } \\
\text { the Estimate }\end{array}$ & $\begin{array}{l}\text { Durbin- } \\
\text { Watson }\end{array}$ \\
\hline 1 & $.915^{2}$ & .837 & .833 & 4.316 & 1.625 \\
\hline
\end{tabular}

a. Predictors: (Constant), Pengendalian Stress Kerja, Pengembangan

Karier Pegawai

b. Dependent Variable: Kinerja Pegawai

Sumber: Data diolah menggunakan program SPSS

Berdasarkan tabel di atas ditemukan bahwa hubungan antara pengendalian stress kerja dan pengembangan karier pegawai secara bersama-sama terhadap kinerja pegawai di Kantor PT. Woori Bio Corpora Jakarta Selatan adalah positif dan sangat kuat, yaitu sebesar 0,915. Dari table tersebut juga dapat diketahui nilai koefisien determinasi sebesar 0,837 yang menunjukkan kemampuan variable pengembangan karir dan pengelolaan stres kerja mampu menjelaskan 83,7\% variasi kinerja pegawai.

\section{Uji Hipotesis}

Uji hipotesa untuk koefisien korelasi ganda dengan taraf kesalahan, yaitu $5 \%$ dan $\mathrm{DK}=\mathrm{n}-\mathrm{m}-1=72$, maka diperoleh $\mathrm{F}$ tabel $=3,1239$ berarti $\mathrm{F}$ hitung jatuh pada daerah penolakan Ho, maka $\mathrm{Ha}$ diterima. Jadi kesimpulannya adalah koefisien korelasi antara faktor pengendalian stress kerja serta pengembangan karier pegawai secara bersama-sama terhadap kinerja pegawai PT. Woori Bio Corpora adalah signifikan.

\section{Analisa Regresi Berganda}

Analisa regresi linier berganda digunakan untuk mengetahui pengaruh variabel bebas (X1) dan (X2) terhadap variabel terikat $(\mathrm{Y})$. Adapun persamaan regresi yang digunakan dalam penelitian ini adalah: $\mathrm{Y}=\mathrm{a}+\mathrm{b} 1 \mathrm{X} 1+\mathrm{b} 2 \mathrm{X} 2$.

Hasil perhitungan regresi linier berganda dengan bantuan program SPSS adalah sebagai berikut:

Tabel 2

\begin{tabular}{|c|c|c|c|c|c|}
\hline \multicolumn{6}{|c|}{ Coefficients $^{\mathrm{a}}$} \\
\hline \multirow[b]{2}{*}{ Model } & \multicolumn{2}{|c|}{$\begin{array}{l}\text { Unstandardized } \\
\text { Coefficients }\end{array}$} & \multirow{2}{*}{$\begin{array}{c}\text { Standardized } \\
\text { Coefficients } \\
\text { Beta } \\
\end{array}$} & \multirow[b]{2}{*}{ t } & \multirow[b]{2}{*}{ Sig. } \\
\hline & B & Std. Error & & & \\
\hline (Constant) & 23.921 & 3.997 & & 5.985 & .000 \\
\hline Ilklim Organisasi & 1.459 & .046 & .660 & 10.038 & .000 \\
\hline $\begin{array}{l}\text { Disiplin Kerja } \\
\text { Pegavarai }\end{array}$ & .323 & .066 & .324 & 4.928 & .000 \\
\hline
\end{tabular}

a. Dependent Varriable: Produltivitas Kerja Pegavai

Sumber: Data diolah menggunakan program SPSS

Berdasarkan hasil analisa regresi di atas, maka dapat disusun persamaan regresi, yaitu: $\mathrm{Y}=23,921+1,459 \mathrm{X} 1+$ $0,323 \mathrm{X} 2$. Kemudian interpretasi dari persamaan tersebut adalah sebagai berikut:

1) Konstanta $(a=23,921)$, artinya angka ini menunjukkan kualitas kinerja pegawai, yaitu pada saat pengusaha Kantor PT. Woori Bio Corpora Jakarta Selatan tidak sama sekali memiliki kualitas pengembangan karier pegawai yang baik dan juga Kantor PT. Woori Bio Corpora Jakarta Selatan tidak memiliki kualitas pengendalian stress kerja yang baik sama sekali. 
2) Koefisien regresi (b1 = 1,459), artinya jika kualitas pengembangan karier pegawai yang terjadi bertambah sebesar satu kali maka kualitas kinerja pegawai Kantor PT. Woori Bio Corpora, Jakarta Selatan akan bertambah sebesar 1,459 kali.

3) Koefisien regresi ( $\mathrm{b} 2=0,323)$, artinya jika tingkat kualitas pengembangan karier pegawai yang terjadi bertambah sebesar satu kali maka kualitas kinerja pegawai PT. Woori Bio Corpora, Jakarta Selatan akan bertambah sebesar 0,323 kali.

\section{KESIMPULAN \\ Simpulan}

Berdasarkan hasil analisa data penelitian serta pembahasan yang telah dilakukan, maka sebagai jawaban dari permasalahan yang ada dalam penelitian ini dapat disimpulkan sebagai berikut:

1) Terdapat hubungan positif antara pengendalian stress kerja dan pengembangan karier pegawai terhadap kinerja pegawai pada Kantor PT. Woori Bio Copora, baik secara sendiri-sendiri maupun bersama-sama.

2) Faktor pengendalian stress kerja adalah faktor yang akan memberikan kontribusi terbesar terhadap peningkatan kinerja pegawai pada Kantor PT. Woori Bio Corpora, Jakarta Selatan.

\section{Saran}

Saran-saran yang dapat penulis sampaikan terkait dengan hasil penelitian pada Kantor PT. Woori Bio Copora antara lain yaitu:

1) Pimpinan Kantor PT. Woori Bio Corpora harus lebih memperhatikan faktor pengendalian stres kerja para pegawainya. Terdapat dua faktor penyebab atau sumber munculnya stres atau stres kerja, yaitu faktor lingkungan kerja dan faktor personal. Faktor lingkungan kerja dapat berupa kondisi fisik, manajemen kantor maupun hubungan sosial di lingkungan pekerjaan.
2) Perencanaan karier harus dilakukan mulai dari jenjang Karier yang paling rendah sampai yang paling tinggi. Perencanaan karier seorang pegawai, akan memberikan beberapa keuntungan antara lain: (a) Mengurangi tingkat turn over pegawai, (b) Meningkatkan potensi pegawai dalam bekerja, (c). Pengembangan pegawai untuk promosi lebih mudah, dan (d). memberikan kepuasan kerja pada pegawai. Agar karier yang sudah direncanakan dapat ditingkatkan maka dilakukan pengembangan karier, dengan cara: (a) Meningkatkan prestasi kerja, (b) Meningkatkan kesetiaan dan loyalitas terhadap Kantor PT. Woori Bio Corpora, dan (c). Memiliki mentor dan sponsor.

\section{DAFTAR PUSTAKA}

Bhagwan. (1994). Public Administration. Alexander Hamilton Institute.

Davis, Keith dan William B. Werther. (1986). Human Resources and Personnel Management ( $3^{\text {rd }}$ ed). New York: McGraw Hill International Edition.

Flippo, Edwin B. (1998). Manajemen Personalia. Jakarta: Erlangga..

Gibson, James, L, dkk. (1996). Organisasi, Perilaku, Struktur, Proses (Nunuk Adiami, Penerjemah). Jakarta: PT. Grasindo.

Handoko, T. Hani. (2000). Manajemen Personalia dan Sumber Daya Manusia. Yogyakarta: BPFE.

Manulang. (2004). Manajemen Personalia. Jakarta: Ghalia Indonesia.

Namawi, Hadari. (1998). Manajemen Sumber Daya Manusia (untuk bisnis yang kompetitif) (2 ed). Yogyakarta: Gajah Mada Universitas Press.

Rivai, Veitzhal dan Sagala, Ella, M. (2011). Manajemen Sumber Daya Manusia.

Schermerhorn. (1994). A Career is a Set of Work Choices and Activities Representing What a Person does for 
a Living. New York: McGraw Hill International Edition.

Silalahi, Bennett. (2014). Corporate Culture and Performance Appraisal. Jakarta: Sekolah Tinggi Ilmu Manajemen - LPMI.
(2014). Manajemen

Sumber Daya Manusia. Jakarta: Sekolah Tinggi Ilmu Manajemen LPMI. 